\title{
O Ódio Como Afeto Político: Sobre A Composição Do Populismo De Extrema-Direita No Brasil
}

\author{
Felipe Castelo Branco1
}

\section{RESUMO}

O ódio aparece nas obras de Freud, Benjamin e Arendt como um importante instrumento político que de certa forma determina o encaminhamento de tendências autoritárias e não-autoritárias das organizações políticas. Neste artigo, busco mostrar como a estrutura institucional das democracias não são capazes de evitar uma destruição interna da própria democracia, mas possibilitam um tratamento simbólico do ódio. A partir dessa reflexão, desejo analisar alguns desdobramentos do fenômeno do "bolsonarismo" atual no Brasil.

Palavras-Chave: Ódio; Psicanálise; Filosofia política; Bolsonaro; Democracia.

1Psicanalista. Professor de Filosofia Política no departamento de Filosofia da UFF. Doutor em Filosofia pela PUC-Rio e doutor em Psicanálise pela UERJ. Membro do Corpo Freudiano, seção Rio de Janeiro. E-mail: felipecastelobranco@terra.com.br. 


\section{Democracia e Autoimunidade}

Ao nos referirmos ao conceito de 'democracia', incluímos sob esse conceito um vasto campo de "possíveis", que podem assumir uma incontável variedade de formas políticas. Nesse sentido, 'democracia' é um conceito sem forma definida e sem organização própria. Por exemplo, entre as formas políticas assumidas por esse conceito, devemos contar a democracia liberal, mas igualmente formas de democracia radical, de democracia plebiscitária, de democracia social, de democracia representativa, de democracia autoritária, de democracia direta, de democracia indireta, de democracia deliberativa, apenas para elaborar uma lista que não tem a intenção de ser exaustiva. Pelo fato mesmo de não possuir uma forma unificada e definida, o que chamamos historicamente de democracia não tem sido forçosamente avesso ao que por vezes consideramos como formas de violência antidemocráticas. Desde seu surgimento na Grécia clássica, passando pela modernidade e pela contemporaneidade, as democracias ocidentais conviveram e por vezes continuam convivendo relativamente bem com a escravidão, com os colonialismos, com o imperialismo, com a xenofobia, com os despotismos e com os fundamentalismos religiosos. Portanto, é preciso admitir que o que há de comum entre todas as formas possíveis de democracia jamais diz respeito a uma estrutura de governo comum a todas essas formas, mas, antes, à ideia de que toda democracia faz parte de um conjunto de processos políticos. Esses processos possuem a característica de se apropriarem das condições específicas dos contextos sociais de cada momento histórico, buscando ampliar o que podemos chamar de um "horizonte de libertação" político. Esse processo de ampliação de um horizonte de libertação é da ordem de um processo sem fim definido. Mesmo em meio a todas as suas diferenças de forma, as democracias devem forçosamente defender um horizonte de liberdade que seja capaz de alcançar o maior índice possível de igualdade (liberdades coletivas), colocando o acento do poder sobre o povo (demos).

No entanto, existem certas condições sociais e sistemas de pesos e contrapesos políticos que devem ser considerados quando na construção de um "povo". Aquilo que se reconhece como sendo "o povo" em uma democracia, possui sempre e forçosamente certos limites. E, portanto, partindo dos limites daquilo que, a cada momento histórico, pode ser considerado o povo, é fundamental se perguntar: 

No Brasil

como se estabelecem os limites do que pode ser considerado o povo? Quem esse conceito de povo exclui? Por exemplo: entre os gregos antigos, o povo que participava ativamente da democracia se reduzia ao homem branco autóctone (isto é, nascido em solo ateniense). Sob os efeitos da Revolução Francesa e dos movimentos de mulheres, o povo inclui o homem e a mulher branca, nascidos na Europa. A partir dos reflexos da Revolução Haitiana e dos conflitos no interior da democracia norteamericana, o povo passa a incluir, por exemplo, os negros e ex-escravos. Nesse sentido, as lutas pelo reconhecimento de direitos dos homossexuais, das mulheres, dos indígenas e quilombolas, dizem respeito a forças que impulsionam a ampliação do "horizonte de libertação" democrático, que expandem o conceito democrático de povo. O "povo" - e com ele, a democracia - diz respeito a uma espécie de corpo que se expande e se contrai, a partir das condições particulares do processo democrático, em nome de direitos universais que garantiriam liberdades em expansão e condições de igualdade. Uma vez mais: o processo democrático é movido por uma força que corresponde a esse esforço de ampliação - que pode igualmente se contrair - de um horizonte de libertação (individual e coletivo) e da constituição de condições de igualdade que devem ampliar o conceito político de povo. Ora, a ampliação desse "horizonte de libertação" respeita um modelo bottom-up, no sentido de que é forçosamente "imposto pelos excluídos" (Balibar), por aqueles que estão na base da pirâmide social, em uma força que é movida de baixo para cima.

Eis aqui a primeira contradição interna à toda democracia: quanto mais 0 processo democrático amplia a noção de povo e aumenta os signatários que terão sua voz reconhecida politicamente, mais interesses contraditórios entre si passam a conviver no mesmo espaço democrático. Desta forma, o conflito social e o ódio devem em toda democracia se institucionalizar, integrando politicamente ao corpo social aquilo que anteriormente era da ordem da simples violência social.

Pelo fato mesmo das democracias não possuírem forma definida, pelo fato do conceito de democracia não poder se representar como uma identidade entre todas as formas que assume - não sendo, portanto, idêntico a si mesmo -, a democracia igualmente não possui limites definidos (ao contrário do conceito de povo, cujos limites se expandem e se contraem). Portanto, a democracia não está em franca oposição a outra coisa, a um "outro" de si definido. A democracia não se coloca em oposição ao fascismo ou à militarização da vida, por exemplo. Nesse sentido, toda democracia, ao 
contrário das formas clássicas de ordenamento político, é "autodestrutiva" ou, mais precisamente, ela é dotada do que Jacques Derrida (DERRIDA, 2003) chama de uma estrutura de autoimunidade.

Quando falamos de autoimunidade ou de doenças autoimunes, nos referimos às potencialidades que possuem os organismos vivos (e de um organismo político como a democracia) de utilizar seu próprio sistema de defesas, não apenas na tentativa de expelir e manter afastadas de si as ameaças externas, mas igualmente como forma de destruir as condições de estabelecimento e funcionamento de seu próprio organismo. A democracia não depende de "forças externas" a si para enfrentar as condições e os instrumentos de sua própria eliminação. O movimento democrático é análogo ao movimento freudiano da pulsão de morte: sem um investimento de sexualidade nos processos democráticos, a tendência das democracias é reduzir a zero e à morte suas tensões internas, que representam a vida de seu organismo. Dito de outro modo, todo processo democrático que se torna incapaz de trazer à luz do debate público sua destrutividade e a elaboração de seu ódio recalcado (ódio de classe, ódio racial, desigualdades e hierarquização social, homofobia etc.), torna automaticamente impossível o vínculo sexual e o laço republicano entre os indivíduos. Nesse sentido, é preciso ter clareza de que os processos formais em que se incorporam o processo democrático (sua dinâmica eleitoral, de referendo ou plebiscitária, por exemplo) não garantem por si mesmos a perpetuidade da própria democracia. Nenhuma institucionalidade democrática pode assegurar que o resultado de seus processos será a escolha da democracia pela própria democracia. O que a processualidade das instituições democráticas garante, diz respeito sempre o que Derrida chama de maioria aritmética, isto é, ela assegura simplesmente a legitimidade institucional da escolha feita pela maioria numérica do povo, sem levar em consideração as condições sociais e históricas de sua escolha, tampouco suas consequências políticas.

Portanto, um dos mais nocivos efeitos da autoimunidade democrática - em uma processualidade que assegura a maioria numérica de maneira incondicional - diz respeito ao fato de que o próprio processo democrático pode escolher, democraticamente, o fim da democracia. O procedimento democrático não garante a perpetuidade da democracia, mas pode significicar sua própria autoaniquilação, por 

No Brasil

meio da defesa legítima de seus direitos fundamentais - como, por exemplo, a liberdade, a igualdade jurídica e o sufrágio universal. Os totalitarismos fascistas, o nazismo e boa parte dos despotismos nacionalistas que chegaram ao poder ao longo do século XX foram eleitos através de processos eleitorais legítimos, que reconheciam a igualdade segundo o voto e asseguravam a liberdade individual. Na Alemanha, a figura de Hitler, além de ter sido eleito democraticamente, iniciou sua perseguição aos judeus através da aprovação de uma lei de desnacionalização no parlamento, isto é, governando dentro dos limites da constituição.

\section{Freud ANTI-CONTRATUALISTA}

Tradicionalmente na filosofia política, existe um modelo canônico de interpretação sobre a origem do poder Estado em seu "momento originário" de fundação e de formação da república: trata-se da teoria do Contrato Social. A teoria do contrato social opera ao mesmo tempo como fundamentação ontológica e como legitimação da força estatal sobre os corpos políticos e sobre o corpo social. A mais representativa entre essas teorias contratualistas é aquela de Thomas Hobbes, exposta em sua obra Leviatã (HOBBES, 2003). Para Hobbes, a obediência ao poder político não possui base natural (Hobbes corresponde à ruptura com a fonte transcendente que oferece legitimidade ao poder político medieval), e o estado natural da humanidade - que Hobbes chama de Estado de Natureza - é visto como necessariamente pré-político (ou apolítico). Esse Estado de Natureza é cheio de insegurança e de ameaças: sem um governo e uma autoridade acima dos membros do corpo social, nenhuma transgressão será punida de maneira justa (provocando um estado recorrente de guerras, violência física e de transgressões), e a relação entre os indivíduos assume a forma de uma reunião caótica marcada pelo medo: é nesse contexto que está instaurada a chamada guerra de todos contra todos, eternizada pelo Leviatã.

O destacamento vertical, que funda o poder político do Estado, é motivado, portanto, por uma economia do medo, que emana dos indivíduos no próprio estado de Natureza em seu apelo por uma punição distributiva e justa. A fundação do Estado é a promessa do fim da guerra generalizada e da instauração de uma lei capaz de finalmente instaurar a linha divisória entre o justo e o injusto. Assim, os homens, abandonando o Estado de Natureza, se reunem e abrem mão de sua liberdade 
individual ao se submenter, em conjunto, ao poder centralizado e indivisível de um soberano que irá liderar o Estado. O nascimento do Estado e da república diz respeito ao ato praticado por cada indivíduo de ceder uma parcela de sua liberdade e direito de auto-governo individual à um soberano que possa exercer seu poder de coerção e punição modo incontestável. A partir desse gesto, a violencia e o ódio que originalmente pertencem ao Estado de Natureza são sufocados, e o conflito entre vontades e indivíduos é eliminado no Estado político. A violência do Estado de Natureza é superada e eliminada do corpo social.

Em seu clássico artigo "Totem e tabu", Sigmund Freud vai igualmente refletir sobre a origem do poder político e da organização da sociedade, buscando dados sobre as relações de parentesco entre os povos primitivos totêmicos. Embora 0 interesse primordial de Freud seja a origem da interdição do incesto e da neurose, a reflexão freudiana possui um grande interesse político, especialmente em seu recurso e interpretação à obra de importantes antropólogos de sua época como James Frazer, Émile Durkheim, Herbert Spencer, John Lubbock, psicólogos como Wundt, biólogos como Darwin, e filósofos como Robertson Smith. Freud encontra em Darwin a ilustração de uma ordem social primitiva, que este último nomeia de "horda primitiva", que consiste em um grupo de indivíduos que permanecem submetidos a um pai que é invejado e temido por seus filhos que futuramente constituirão um clã totêmico. Esse pai da horda possui um poder desproporcional (e verticalizado) em relação a seus filhos que jamais é compartilhado com nenhum deles. Em função dessa desproporcionalidade de poder, o Pai goza livremente e submete os outros membros do bando a suas leis e caprichos, concentrando inclusive o poder de posse sobre todas as mulheres do grupo. No trabalho de Darwin, a desproporcionalidade de poder que atravessa a horda primitiva leva os filhos a se organizarem para eliminar o pai. Com esse ato extremo de violência contra a hierarquia de poder que está na base da ordem social, a horda finalmente se desintegra, desfazendo a possibilidade de qualquer nova organização social.

Mas, ao contrário das conclusões darwinianas e atravessado pela leitura de Robertson Smith, Freud vai recompor a descrição da constituição da horda primitiva, defendendo que, após o assassinato do pai e da destituição de seu poder, a horda passa finalmente a viver como uma comunidade. Portanto, ao contrário da 

No Brasil

compreensão de Darwin, a organização social freudiana se inicia a partir de um ato de violência que tem lugar no assassinato daquele que detém o poder tirânico vertical, isto é, o pai da horda. Assim, mesmo após o ato de violência (o parricídio), um laço social se estabelece e a união social dos membros do grupo se estrutura através da união daqueles que praticaram o ato contra a autoridade desproporcional do pai, que hierarquizava o gozo. Ao contrário do Contrato Social de Thomas Hobbes, a organização da horda primitiva não se estabelece como "pacificação da violência" através da mediação do Estado, mas ela nasce da violência contra a autoridade que deseja concentrar todo o poder para si. Nesse sentido, a visão "republicana" de Freud não nega a origem violenta do Estado (em oposição a Hobbes), ao mesmo tempo em que entende que essa violência apenas assegura sua legitimidade se permanece voltada contra a hierarquia e concentração de poder, que passa a ser redistribuído através do ato de fundação da sociedade. A ordem social (e poderíamos dizer, a ordem democrática) se sustenta inicialmente na institucionalização simbólica do ódio contra a tirania e a concentração de poder. Por esse motivo, o totem tem a função de inscrever o ódio e a recordação do assassinato originário do Pai/Tirano no centro da memória coletiva. De que modo?

Após o parricídio, a horda freudiana estabelece a fundação de um totem que se torna uma espécie de "substituto do pai", no sentido de que permite ao corpo social uma constante recordação de seu antigo lugar de poder, através de sua institucionalização simbólica. A interdição generalizada estabelecida pelo poder do pai totêmico (interdição do gozo absoluto dos bens e das mulheres do clã), não depende mais de sua existência real, mas passa a ser incorporada pelos próprios filhos na forma de uma obediência simbólica. A partir do totem, instaura-se uma lei de interdição válida igualmente para todos. Desta forma, o ato violento e parricida na origem da sociedade se desdobra em uma ordem "jurídico-política", em que o corpo social encontra sua unidade política através do ato violento que elimina o poder hierárquico, embora esse ato não elimine a autoridade (expressa pelo próprio totem), nem o desejo ambivalente dos membros da horda pelo poder de exceção (e por ocupar o antigo lugar do pai).

Se o ódio contra a tirania não for rememorado e cultivado pela memória coletiva, ele tende a se converter novamente em uma violência fratricida que ameaça a ordem social. Portanto, o que une os filhos da horda em um corpo social é, ao 
mesmo tempo, a ausência do Pai morto (representado pelo totem) e o ódio contra seu lugar de exceção. A inauguração simbólica do totem passa a representar a proibição "institucional" de que qualquer membro do clã se identifique ao pai tirânico e busque ocupar o lugar vazio deixado por ele. A partir da instauração do totem, o ato de violência que funda a lei se torna ilegal na comunidade - daí a origem da culpa (que para Freud está no fundamento da organização social e da inscrição simbólica). A função do Totem é a de lembrar a todos a respeito dos riscos de autodestruição (ou de autoimunidade) do tecido social, caso aquele ato de violência desregrada retorne no seio da sociedade - uma violência endogâmica e fratricida que ameaça o próprio tecido social -, se um dos membros do corpo social ousar ocupar novamente o lugar de exceção e de concentração de poder do Pai tirânico. O corpo político de Freud se sustenta em uma lei que nasce partir de um ato de ódio, mas que faz circular esse ódio, tanto como ato fundador contra a tirania, quanto como lei que institucionaliza a recordação a respeito da ameaça ao próprio corpo social horizontal case esse ato violento retorne fora da institucionalidade simbólica. Através do totem, o pai é admirado (como um líder poderoso e temido) e odiado (como um déspota que concentrava todo o gozo). Eis a necessária ambiguidade do poder na manutenção do tecido social2.

\section{O Ódio, INSTRUMENTo Político}

Diante da iminência da chegada do partido nazista ao poder, o filósofo alemão Walter Benjamin passa a denunciar em seus escritos uma das marcas mais fundamentais dos autoritarismos políticos: eles permitem às massas expressarem seu ódio, mas não reivindicar direitos. Mesmo que as relações de classe se tornem cada vez mais desiguais, mesmo que as condições de vida dos trabalhadores se tornem

\footnotetext{
${ }_{2}$ Freud entende que, de tempos em tempos, uma celebração - em Totem e tabu representada pelo banquete totêmico - precisa acontecer no seio da sociedade (assim como eleições, plebiscitos e referendos acontecem em democracias). A refeição totêmica corresponde à incorporação do ato de violência à cultura, com o objetivo de elaborar o ódio parricida através da distribuição de parcelas do poder paterno aos membros do clã e, ao mesmo tempo, negando a responsabilidade individual e direta de cada um dos membros do clã pela matança. Do mesmo modo, o sintoma neurótico tem a mesma função de repetição que nega, para a consciência, a responsabilidade do neurótico em seu desejo incestuoso e parricida.
} 

No Brasil

cada vez mais precarizadas e mesmo que a população nacional sinta-se cada vez mais insegura em relação a seu futuro, na moldura dos poderes autoritários não é possível questionar as desigualdades de classe, embora a expressão de um ódio, que é frequentemente efeito dessa relação, seja um dos principais instrumentos políticos do populismo autoritário de caráter nacionalista. Nesse sentido, Benjamin afirma taxativamente: "o fascismo permite que [as massas] se exprimam, conservando, ao mesmo tempo, essas relações [de classe]" (BENJAMIN, 1994, p. 195). A instrumentalização do ódio e a mobilização permanente da população para uma guerra sempre iminente (mesmo que fictícia) é a forma princeps de transformação do ódio aos privilégios, concentrações de poder e produções de desigualdade, em instrumento político: "somente a guerra [e especialmente a guerra total] permite mobilizar em sua totalidade os meios técnicos do presente, preservando as atuais relações de produção" (BENJAMIN, 1994, p. 196). Mantendo intactas as relações de classe e seus efeitos - desemprego e acirramento das disputas por trabalho inclusive em relação a estrangeiros e imigrantes, pauperização dos assalariados, desigualdade crescente, informalidade, etc. - o autoritarismo populista, no entanto, se vale do afeto primordial que a insegurança social produz - isto é, o ódio - não como forma de combate formal e institucional às desigualdades, concentrações tirânicas de poder e renda ou restrições de liberdade, mas como uma espécie de rastilho de pólvora que mobiliza e dá esteio a ações políticas autoritárias.

Foi Hannah Arendt quem melhor revelou como um ódio difuso, distribuído mais ou menos por toda a parte, foi cooptado e instrumentalizado no período anterior à Segunda Guerra Mundial, operando como instrumento de ascensão dos totalitarismos no seio das democracias europeias:

\footnotetext{
A inflação destruiu toda a classe de pequenos proprietários a ponto de não mais deixar esperança de recuperação, o que nenhuma crise financeira havia feito antes de modo tão radical. O desemprego, quando veio, atingiu proporções fabulosas, sem se limitar às classes trabalhadoras mas alcançando a nação inteira, com poucas exceções [...] O ódio [...] começou a desempenhar um papel central nos negócios públicos de todos os países, de modo que o cenário político, nos anos esmagadoramente calmos da década de 20, assumiu uma atmosfera sórdida e estranha de briga em família [...] Nada talvez ilustrasse melhor a desintegração geral da vida política do que esse ódio universal vago e difuso de todos e de tudo, sem foco que the atraísse a atenção apaixonada, sem ninguém que pudesse ser responsabilizado pelo estado de coisas - nem governo, nem burguesia, nem potência estrangeira (ARENDT, 2012, pp. 369, 270).
} 
Esse ódio difuso e vago, no entanto, apenas ganha serventia política quando instrumentalizado e mobilizado contra um "outro" capaz de representar uma ameaça viva o suficiente a ponto de produzir a sensação de unidade social entre pessoas que permanecem à espreita, vigilantes diante de um risco velado, mas iminente. Ao mesmo tempo, essa ameaça deve estar morta o suficiente a ponto de não representar uma desintegração real da unidade social, resultado de uma luta desproporcional de poder em que o líder populista, redentor dos sofrimentos de seu povo, iniciaria sua batalha já derrotado ou com poucas chances de vitória. O populismo nacionalista inevitavelmente nasce no combate a um inimigo, imaginário ou não, de saída derrotado, diminuído, apequenado.

\section{A Construção Do Populismo Conservador De Jair Bolsonaro}

A eleição de Jair Bolsonaro para a presidência da república brasileira trouxe consigo uma perplexidade que talvez possa ser sintetizada em uma pergunta central: como é possível que um homem com uma biografia militar tão pobre e com uma biografia política tão mediana, como tantos outros políticos orgânicos de pouca expressividade, tenha sido alavancado ao lugar de um representante das forças militares e do "novo" na política? A resposta a essa perplexidade não é simples. Embora seja verdade que a biografia militar de Bolsonaro seja pobre, não é possível afirmar, ao menos no plano militar, que ela seja monótona. Quando jovem militar, Bolsonaro nunca deixou de se envolver em escândalos, entre eles a acusação de planejar e liderar a operação "Beco sem saída", apenas nove meses antes de disputar sua primeira eleição como candidato a deputado estadual pelo Rio de Janeiro. Essa operação consistiu em um plano para explodir um conjunto de bombas em quarteis generais e no fornecimento de água da cidade, como forma de reivindicar aos militares de mais alta patente um aumento nos soldos aos baixa patente. Na ocasião, o médico e coronel da reserva Jorge Coelho de Sá afirmou ao Jornal do Brasil que, com uma mobilização de tal espécie, Bolsonaro seria capaz de receber amplo apoio de jovens militares em sua futura candidatura. Foi precisamente o que aconteceu. Em outra versão para a operação "Beco sem saída", difundida pelo coronel e pesquisador militar 

No Brasil

Geraldo Cavagnari em entrevista ao Jornal do Brasil em 3 de setembro de 19873, Bolsonaro é visto como o mentor de um atentado contra o exército que visava "desestabilizar a transição democrática", de modo a produzir dúvidas a respeito da autoria do atentado, pois, segundo o coronel, o grupo liderado por Bolsonaro era contrário ao fim da ditadura civil-militar brasileira.

Desde muito cedo em sua carreira, Bolsonaro se pautou por uma oposição aberta à institucionalização do poder militar nos quadros da abertura democrática liberal do país, após o fim do período ditatorial. Deste modo, Bolsonaro permaneceu conectado a uma corrente ideológica militar - mais popular entre o "baixo clero" da instituição - que se manteve aquecida em meio a uma militância que entendia ser nociva a transição democrática. Essa corrente se insurgia contra certo conjunto de inimigos - entre eles políticos e militares que passaram a compor os altos escalões dos poderes da república - considerados fracos e pouco patrióticos, por abraçar um vínculo institucional com a democracia liberal brasileira. Quando candidato à câmara, Bolsonaro terá sucesso em converter os militares apoiadores dessas pautas em sua base eleitoral. O que implica em reconhecer que a base da carreira militar e política de Bolsonaro se sustentou no apoio de membros do "baixo clero" militar - seu eleitorado cativo. Ao expor publicamente seus ídolos militares, Bolsonaro não costuma escolher figuras como Figueiredo, mas venera abertamente o coronel Ustra. Seu modelo militar não é aquele dos generais do alto comando ou da transição democrática, mas os militares dos porões, do trabalho sujo e sangrento da tortura. $A$ carreira política de Bolsonaro jamais tocou os altos escalões das Forças Armadas e, mais do que isso, sua biografia sempre foi considerada um péssimo exemplo entre coronéis e generais. Em seu livro autobiográfico, o general Ernesto Geisel considerou Bolsonaro um mau militar por cedo se envolver em insurreições pelas quais ele só não foi devidamente punido em função do receio dos generais de transformar esses focos de agitação em uma revolta organizada.

Portanto, é fundamental notar, nesse cenário, que a luta inicial de sua carreira política é uma luta contra a institucionalidade democrática (não são poucas as vezes em que Bolsonaro expressa sua nostalgia, não apenas pela ditadura, mas igualmente

3 http://www2.senado.leg.br/bdsf/browse?type=subject\&value=Cavagnari\%20Filho,\%20Geraldo\%20Le sbat. Acessado em 05/2019. 
pelas torturas e assassinatos praticados no período). $\mathrm{O}$ jovem deputado sustentou durante longos anos um eleitorado que permanecia cativado pela mobilização permanente contra um inimigo que, na verdade, não representava efetivamente um grupo "rival" organizado, que ameaçava diretamente os militares. Bolsonaro construiu seu eleitorado se opondo àqueles que buscavam a expansão de direitos, após a abertura democrática, especialmente entre as minorias. Sua carreira política sempre foi alimentada por uma oposição a todos os traços de expansão das liberdades democráticas, de institucionalização de direitos ou de desconcentração de poder. Como é possível, portanto, que tais pautas, sustentadas por nichos tão restritos, tenham sido capazes de eleger um presidente da república?

\section{A Velha Política Orgânica, "Desorganizada"}

Como apontam Benjamin e Arendt, em tempos de crise, um perfil político que estabelece contra si um inimigo claro contra quem ele próprio entende de antemão poder medir forças (desde que aliado a grupos estratégicos que possam apoiá-lo), torna-se o modelo ideal para a capitalização eleitoral e a mobilização de grandes grupos da opinião pública. E foi precisamente esse um dos principais sucessos da campanha presidencial de Bolsonaro: ela soube aproveitar as crises contingentes do cenário político e econômico do país, que se combinaram a seu perfil eleitoral militante (inclusive a eliminação de seu principal rival na corrida eleitoral: o ex-presidente Lula, que catapultou seu capital eleitoral alimentado pelo antipetismo). Além disso, a campanha de Bolsonaro teve sucesso em construir sua imagem como a de um político outsider, que trava uma cruzada solitária contra o poder, dotado apenas de uma campanha pobre e sem apoio dos poderosos. Com essa estratégia, seus articuladores políticos foram capazes, entre outras coisas, de "limpar" a imagem de Bolsonaro de sua própria biografia, afastando de sua imagem eleitoral o fato do então candidato ter composto, por quase 30 anos de sua atuação como deputado, o tão popularmente detestado "centrão". Como o político orgânico que sempre foi, Bolsonaro se aliou a esta casta baixa do parlamentarismo brasileiro, composto por um conjunto de parlamentares e partidos que tendem a se movimentar ao sabor de suas associações com os poderes de ocasião, mobilizados apenas por seus interesses eleitorais e pela força do lobby político. A principal característica do "centrão", que é igualmente a 

No Brasil

característica da carreira política de Bolsonaro, é a perpetuidade no poder (no caso do então candidato a presidente, quase 30 anos de Câmara dos Deputados) e a inconstância em relação a posições políticas, embora mantendo a fidelidade aos interesses de determinada base eleitoral, sempre capaz de assegurar uma nova vitória eleitoral. Os membros do "centrão" se dividem igualmente em vínculos de fidelidade a pautas ligadas às bancadas mais poderosas do poder parlamentar: a bancada ruralista da agroindústria, a bancada armamentista, vinculada ao lobby militar e à indústria de armas, e a bancada evangélica, o mais poderoso curral eleitoral do país. Nesse sentido, em toda sua carreira política como deputado, Bolsonaro se manteve articulado com as forças mais retrógradas e igualmente mais poderosas, política e economicamente, da estrutura parlamentar brasileira.

Essas mesmas forças representam o núcleo duro da corrupção política e empresarial ligada ao Parlamento. Por exemplo, apenas durante o período que corresponde aos governos do PT, Bolsonaro foi filiado ao PTB, no período entre 2003 e 2005, partido presidido por Roberto Jefferson e que tinha entre seus membros Paulo Maluf e Cristiane Brasil. Note-se que o período de filiação de Bolsonaro ao partido é precisamente o mesmo em que, através da confissão do próprio presidente do partido, o PTB teria participado ativamente, como aliado do PT, no escândalo que ficou conhecido como "mensalão". Outro exemplo é sua filiação ao PP entre 2005 e 2016, após sua saída do PTB. Durante os onze anos em que Bolsonaro foi membro do partido, o PP atingiu recordes imorais no campo partidário brasileiro, sendo, por exemplo, o partido com a maior quantidade de membros condenados pela operação Lava-Jato (com mais condenações do que o próprio PT). Enquanto o PP teve 31 membros condenados na operação, o PT teve 6 membros indiciados e condenados. E a situação atual de seu vínculo partidário não progrediu em relação a seu passado parlamentar. O PSL, atual partido do presidente da república, é uma espécie de dissidência militar do PP, sendo considerado o partido menos transparente do Brasil4 e tem se envolvido em constantes escândalos eleitorais, especialmente por prática de Caixa 2. Antes das eleições de 2018, o PSL possuía apenas 8 congressistas em seus 
quadros, embora 18 membros do então minúsculo partido fossem condenados por corrupção, tornando-se "ficha suja".

Apesar disso, a campanha presidencial de Bolsonaro teve êxito em manter sua imagem afastada de todos seus vínculos políticos com os donos do poder econômico, com a política tradicional do "centrão" e com os escândalos de corrupção, contra os quais ele buscou promover a imagem de líder de uma cruzada antiestablishment. A estratégia política da equipe de Bolsonaro teve êxito igualmente em apresenta-lo como um candidato que não contava com nenhum apoio nas engrenagens do poder econômico, inclusive no que diz respeito a sua participação na mais poderosa onda do cenário político internacional: o vínculo do poder econômico ao apelo eleitoral do populismo de extrema-direita. Observado a partir de um enquadramento internacional mais amplo, o fenômeno Bolsonaro surge como o cruzamento perfeito entre as duas principais forças que tem impulsionado a concentração de poder político e econômico de nosso tempo, a saber: o populismo nacionalista de extrema-direita e a ortodoxia neoliberal.

\section{SuRfando NA ONDA Do PODER}

A eleição de Bolsonaro é produto de um fenômeno de poder que se reproduz em escala internacional. A viabilidade eleitoral de Bolsonaro seria extremamente dubitável se sua campanha não tivesse fincado os pés no apoio das duas mais importantes estruturas de poder do mundo atual. A primeira delas é a nova forma de mobilização populista e nacionalista, que tem se insurgido contra as ameaça à "unidade nacional", alimentando-se do uso de dispositivos tecnológicos de disparos de mensagens em redes sociais a fim de manter seus alvos na constante tensão (e medo) contra uma ameaça iminente. $O$ uso dos disparos em massa, através de aplicativos de mensagens, consegue alimentar em tempo real a participação e 0 engajamento da base militante de um candidato ou causa, a partir de um pequeno estímulo - uma imagem, uma frase, um vídeo com legenda, um "tweet" etc. - que funciona como uma espécie de faísca capaz de reacender a indignação massiva e a sensação individual de fazer parte de um conjunto maior de "combatentes", em favor da causa nacional. Essa estratégia continua sendo usada pelo poder executivo brasileiro, sob o comando de Bolsonaro, de modo a recorrentemente produzir uma 

No Brasil

mediação entre os acontecimentos nacionais e a base popular de apoio ao governo. A cada acontecimento noticiado em âmbito nacional, seja uma ação do governo ou um dos escândalos que tem ferido sua imagem, o governo divulga um comentário oficial através de seu porta-voz, ao mesmo tempo em que divulga uma espécie de legenda extra-oficial a esses eventos, em linguagem popular simples e reduzida, que explicita como a base de apoio ao presidente deve interpretar aquele acontecimento preciso. Essa "legenda extra-oficial" aos acontecimentos nacionais é disparada de maneira descentralizada em grupos de mensagens, em vídeos de youtubers e blogueiros, que "interpretam" os eventos políticos, sempre a favor do presidente, de modo a fornecer argumentos à sua militância, minimizando o impacto dos mais desastrosos fatos ou denunciando a responsabilidade por tais acontecimento a uma espécie de "complô", que teria interesse em destruir a pátria. Deste modo, os acontecimentos políticos nacionais são despolitizados e sofrem um esvaziamento em relação a dados e apurações, em nome de um apelo afetivo ao amor à nação, ao patriotismo e ao vínculo nacionalista.

O apoio do milionário norte-americano Steve Bannon à campanha de Bolsonaro parece ter sido crucial neste ponto. Bannon é o principal estrategista político no mundo atual a se valer do modelo do disparo eletrônico de mensagens, com a finalidade de evocar um apelo nacionalista e populista ao produzir legendas populares capazes de unificar em bloco a interpretação de acontecimentos políticos importantes. Embora a versão popularizada a respeito da campanha presidencial bolsonarista afirme que sua eleição dependeu exclusivamente da colaboração espontânea de seus apoiadores, Bannon admite ter prestado consultoria a Bolsonaro, através dos filhos e dos assessores do então candidato, mantendo-se na liderança de suas estratégias de campanha5. O sucesso da participação de Bannon na eleição presidencial de Donald Trump nos Estados Unidos e na eleição de Bolsonaro no Brasil, fez com que ele passasse a ser solicitado por um grande número de outros grupos de extrema-direita, especialmente na campanha do Rassemblement National de Marine Le Pen, na França, e na campanha da Liga Norte de Matteo Salvini, na Itália. Ambos tiveram sucesso significativo nas eleições europeias recentes, a partir do apoio de Bannon. $O$

5 https://brasil.elpais.com/brasil/2019/03/24/internacional/1553454729_290547.html. Acessado em 05/2019. 
uso das redes sociais e o disparo em massa de mensagens sem fonte confiável - as chamadas fake news - são uma constante em todas essas corridas eleitorais. Além desses dois candidatos de extrema-direita, um dos mais agressivos nacionalistas da extrema-direita europeia, o autoritário Viktor Orbán da Hungria, é igualmente um dos protegidos do milionário estrategista norte-americano. Portanto, é necessário compreender a eleição de Bolsonaro em um cenário internacional, como uma peça fundamental nessa estratégia política como que tem tido um avassalador sucesso ao redor do mundo, elegendo políticos de extrema-direita a despeito de sua qualidade intelectual, política, administrativa ou ideológica. O perfil desses novos populistas de extrema-direita é muito semelhante: seus rivais imediatos, contra os quais eles clamam sua base eleitoral a se manter em estado de alerta, são professores e jornalistas, ativistas e figuras que se opõem a sua posição ideológica e que imediatamente passam a ser considerados "comunistas" ou "esquerdistas", mobilizando toda uma agenda anti-intelectual que mantém ativa a força do que Hebert Marcuse chamou de mobilização total. $O$ fato é que esses rivais são estabelecidos sem base em dados, pesquisas ou qualquer análise efetiva a respeito do impacto real de suas ações sobre a sociedade. Trata-se de uma excitação do imaginário político que busca causas simplórias para justificar o sofrimento social, a pobreza e o "desregramento dos costumes" no mundo atual. Em última instância, trata-se mais uma vez de despolitizar o campo político, esvaziar esse campo dos dados históricos ou de qualquer análise de conjuntura, para substituir o debate por um inimigo a-histórico, sem forma precisa, que seria capaz de corroer a sociedade por dentro sem que ninguém perceba - ninguém, exceto aqueles "bem informados" que acabaram "descobrindo a verdade" graças a seu líder político e ideológico. É nesse cenário que o velho tema ultra-direitista do combate ao chamado marxismo cultural ganhou um espaço eleitoral e ideológico central na última corrida eleitoral brasileira.

A narrativa do "marxismo cultural" tem origem no mundo anglófono após o colapso dos regimes socialistas, e tem obtido certo êxito em continuar alimentando a retórica politicamente útil da ameaça socialista, que construiu a polarização política da guerra fria. Com o desaparecimento das potencias militares e políticas socialistas "reais", os ideólogos do marxismo cultural buscaram, a partir de uma interpretação 

No Brasil

enviesada da obra do marxista italiano Antonio Gramsci, a ideia de que, se o socialismo havia sido derrotado no plano político, a guerra ideológica travada por seus apoiadores havia se transportado para o plano cultural, onde as tendências marxistas continuariam doutrinando e formando seus exércitos, na expectativa de um dia retornar ao poder. O inimigo contra o qual a ultra-direita deveria fazer frente não é mais representado por um Estado, mas está disseminado em meio a professores, jornalistas, defensores dos direitos humanos, feministas, ativistas da causa LGBTQ, militantes em defesa dos direitos civis das minorias etc. Nesse sentido, a ideologia do "marxismo cultural" cumpre um papel político fundamental, ao justificar, em nome do combate à expansão do marxismo, uma oposição a expansão das liberdades democráticas (o que corresponde, como vimos, a um combate à própria democracia), dos direitos das minorias e do combate aos privilégios sociais, que começava a se esboçar no Brasil - e em outras partes do mundo - nos últimos anos. Segundo Jason Wilson, colunista do jornal britânico The Guardian, a ideologia do "marxismo cultural":

permite que aqueles que sofrem com a perda de privilégios sejam encobertos pela vitimização, apontando para uma elite obscura, onipresente e quase estrangeira que está tentando destruir tudo o que é bom no mundo. Ele oferece uma explicação para o declínio das famílias, das cidades pequenas, da autoridade patriarcal e do poder branco [até então] incontestado: trata-se de uma vasta conspiração de esquerda que já dura um século6.

Não é difícil perceber que, apesar de não se valer desde o princípio de sua carreira militar da denúncia de um "marxismo cultural", desde muito cedo Bolsonaro soube manejar eleitoralmente certas pautas políticas que se encaixam com perfeição nas demandas do anti-marxismo cultural. Embora tenha se limitado inicialmente a reunir em torno de si os insatisfeitos com o processo de abertura democrática do Brasil pós-ditadura, Bolsonaro não teve dificuldades em "internacionalizar" suas pautas, se voltando contra a ampliação dos direitos civis e contra pautas ditas "de esquerda", ao surfar em um movimento que ganhava robustez no plano internacional. Essa associação se concretizou definitivamente através do reconhecimento prestado ao ideólogo do mundo virtual, Olavo de Carvalho. Ao contrário de alguns de seus filhos, 
acredita-se que o próprio Bolsonaro jamais tenha travado um efetivo contato com as ideias do ideólogo de extrema-direita; no entanto, o gesto de aproximação do então deputado e futuro candidato à presidência ao grupo de seguidores de Olavo de Carvalho, produziu um efeito simbólico importante para ambos os personagens políticos: para Bolsonaro, sua aproximação a Olavo de Carvalho garante uma aparência de legitimidade intelectual às suas pautas políticas. Para Olavo de Carvalho a aproximação de Bolsonaro ofereceu a seus cursos uma visibilidade nacional que ele jamais alcançara sozinho, além de garantir uma aparência de legitimidade política à sua militância, Ihe sendo oferecido - sem que ele tenha nenhuma experiência no assunto - o papel de "guru" do governo executivo (nesse sentido, suas ideias não correm o risco de serem tomadas como a expressão de frustrações ou devaneios de um ideólogo descompromissado com a realidade).

\section{Afinal, 0 Alvo da insatisfação Deveria Ser o Capitalismo NeOLIBERAL!}

Onde quer que o novo discurso de extrema-direita tenha conquistado o poder no mundo, ao contrário de fortalecer os "estilos de vida tradicionais" e combater as desigualdades sociais, o que tem se produzido é a auto vitimização daqueles que detém o poder político que passa a legitimar um ataque às instituições públicas e democráticas - tribunais, universidades, parlamentos, etc. -, ao mesmo tempo em que tem construído novas oligarquias de poder, compostas apenas por "amigos" e aliados ideológicos7 desses líderes populistas. Grande parte das vezes, e no Brasil não é diferente, amigos e parentes desses líderes populares fazem negócios diretamente com o governo, ou ocupam lugares estratégicos nos três poderes de modo a auxiliar na disseminação das versões extraoficiais do governo populista e no reforço à ideia de que está em curso um ataque ao governo por parte de inimigos "infiltrados", presentes nas instituições públicas. Deste modo, produz-se um discurso que, reproduzido por diversos apoiadores e em diversas direções, sufoca as

7 É verdade que, por vezes, essas novas oligarquias do poder tem deposto a direita liberal de seu lugar tradicional, configurando-se como o mais profundo abalo e a mais nova exigência de reestruturação que a direita jamais sofreu historicamente. Em seguida, a extrema-direita tem chantageado a direita tradicional a se aliar a seu projeto, sob pena de ser aniquilada politicamente. É precisamente o que Bolsonaro tem feito com o DEM e com antigos PSDBistas como João Dória. 

No Brasil

investigações e as matérias jornalísticas oficiais, através de uma denúncia da imprensa como eminentemente aliada ao "marxismo cultural" (mesmo quando se trate de grandes conglomerados de mídia, sustentados pela publicidade das empresas mais capitalistas que existem).

Outra das mais importantes formas de sustentação eleitoral de Bolsonaro, foi o apoio das forças econômicas que dominam o mercado internacional ligadas a agenda do chamado neoliberalismo. Desde a década de 1970 e sobretudo a partir da década de 1980, com o colapso da polaridade entre o capitalismo e o socialismo, a agenda política e econômica que ficou conhecida como agenda neoliberal - porque inspirada em filósofos e economistas como Ludwig von Mises, Friedrich Hayek e Milton Friedman, que recuperavam temas do liberalismo econômico clássico - tem amplamente se disseminado e se instalado como discurso ortodoxo econômico oficial ao redor do mundo. Segundo Hayek - um dos autores neoliberais que possuiu grande poder de influência sobre políticos e economistas britânicos, norte-americanos, suíços e alemães -, sem mudanças radicais no cenário político do Estado de bem-estar social e no campo do direito, as novas crises do capitalismo se tornariam cada vez mais imprevisíveis (porque através da manipulação dos preços e do juros pelo Estado, as informações sobre oferta e demanda se tornariam deturpadas para os agentes econômicos). Mas outra preocupação silenciosa mobilizava igualmente o discurso alarmista dos neoliberais da Escola Austríaca e da Escola de Chicago: se não houvesse uma reformulação radical no modelo de direitos e proteções a trabalhadores e cidadãos que o Estado de bem-estar social produziu na recuperação econômica após a Segunda Guerra Mundial, os custos de produção - sobretudo os custos do trabalho assalariado e dos transportes - se manteriam em patamares muito altos, tornando impraticáveis os preços e uma concorrência competitiva na economia de mercado. Em síntese: o capitalismo se tornaria insustentável. A ideia canônica do pensamento neoliberal é a de que o Estado é um rival ineficiente por princípio, e que o neoliberalismo representaria a libertação das iniciativas individuais dos agentes econômicos, como uma espécie de último suspiro de sobrevivência do capitalismo (lembre-se do que ficou conhecido como "princípio TINA", repetidamente aplicado pela primeira-ministra britânica da época, Margaret Tatcher, que bradava: "There Is No Alternative!" (TINA), ou seja: "não há outra alternativa!"). 
Uma guinada em direção à política neoliberal, até então estranha a carreira política pregressa de Bolsonaro, passou a sustentar eleitoralmente a candidatura do atual presidente da república. Com isso, Bolsonaro surge como o candidato que igualmente receberia apoio do mercado financeiro e dos grandes grupos de capitais (retirando de outros candidatos tradicionais da direita essa "carta na manga"). Com certa dificuldade, Bolsonaro integra em suas breves falas públicas a cartilha ortodoxa do neoliberalismo. Essa cartilha, a despeito das enormes variações de contexto em que tem sido empregada, possui duas características centrais. A primeira delas é a disseminação da ideia de que é preciso retirar o Estado da cena de algumas de suas mais importantes funções tradicionais, como, por exemplo, algumas garantias de direitos e formas de regulação da economia (o que se abrevia com o jargão "enxugar o Estado"). Na realidade, trata-se menos efetivamente de uma "retirada do Estado" e mais de uma intervenção do Estado de modo a transformar políticas e serviços estatais em nichos de mercado. Por exemplo, quando o Estado privatiza serviços e reduz gastos com áreas que são tradicionalmente compreendidas como direitos do cidadão, o Estado deliberadamente e automaticamente transforma direitos e formas de arrecadação estatal em novos mercados privados. Desse modo, o Estado cria mercados novos e em seguida seleciona e entrega ao proveito de empresas e de grupos privados aquilo que antes era compreendido como função pública, sem finalidade lucrativa. Ao concentrar antigos serviços estatais nas mãos de empresas privadas que visam lucro, os usuários daqueles serviços - isto é, a população passam a arcar individualmente com custos que antes permaneciam embutidos em seus impostos. Portanto, a "redução do Estado" é, antes de mais nada, uma forma de transferência de renda dos trabalhadores assalariados para empresas privadas, por meio de uma ação do Estado. Nesse sentido, o poder executivo se vale dos aparelhos de Estado como uma espécie de "testa de ferro" de grupos privados que, apoiados pelas medidas privatistas estatais, passam a lucrar com antigos direitos e serviços públicos. O Estado passa a se comportar como um agente econômico que tem a função de criar o espaço propício para que ações de mercado mais agressivas dos players privados possam acontecer, através de seu auxílio.

A segunda característica fundamental da ideologia neoliberal é a produção de uma espécie de novo conceito de liberdade. Se autoproclamando descendente do 

No Brasil

liberalismo clássico, o pensamento neoliberal é movido por um discurso que prometia libertar os indivíduos do peso e do controle do Estado, limitando o Estado em sua soberania e em sua capacidade de planejar a economia de maneira centralizada. Com isso, defendiam e defendem os neoliberais, estaria afastada a sombra do retorno das ditaduras e dos governos totalitárioss. A ideologia privatista e individualista neoliberal prometia libertar o trabalhador do domínio dos patrões, permitindo que esses trabalhadores abracem iniciativas livres e independentes. Com isso, os intelectuais do neoliberalismo se apropriavam de promessas e lemas característicos do próprio comunismo - mesmo sem produzir comunidade ou coletivização -, em plena polarização política do mundo. Se as lutas por direitos sociais socialistas ou socialdemocratas apontavam para a excessiva exploração do trabalhador e desigualdade nas relações entre trabalhadores e patrões; através de uma economia desregulada e descentralizada - promete ainda o neoliberalismo -, o trabalhador poderia ser seu próprio patrão e permanecer livre para trabalhar como quiser e, como um empresário, depender apenas de sua livre-iniciativa. Essa promessa desaguou nas desregulamentações do trabalho, na fragmentação dos direitos trabalhistas, no crescimento do trabalho intermitente e na chamada "uberização" da vida.

Tampouco, do ponto de vista político, esse apelo à liberdade se efetivou na prática neoliberal. Uma de suas mais importantes experiencias mundiais foi a criação de uma agenda neoliberal, a golpes de força e de tortura, durante a ditadura militar de Augusto Pinochet, no Chile, inaugurando a face de Frankenstein assumida pelo neoliberalismo no hemisfério Sul mundial: uma espécie de liberalismo sem liberdade. Dito de outro modo, trata-se de produzir um Estado pesado para a população, mas "reduzido" para os grupos econômicos. Durante a ditadura Pinochet, um grupo de técnicos da chamada Escola de Chicago, sob a orientação e supervisão de Milton Friedman, ele mesmo discípulo de Hayek, foram convocados a auxiliar os militares autoritários chilenos a implantar um programa de reformas e privatizações no país, sem passar por qualquer consulta popular. Esse grupo de técnicos ficou conhecido

8 Autores neoliberais como Mises e Hayek defenderam deliberadamente esta ideia, ao apontar que toda intervenção do Estado na economia acaba por se aproximar, em maior ou menor escala, da economia planificada de essência socialista. Esta crítica aos economistas socialistas ficou conhecida como o debate acerca do cálculo socialista. Além de criticar a economia planificada socialista - e em seguida o keynesianismo -, Hayek criticava igualmente a noção de justiça social (HAYEK, 2012), que ele entendia ser imprecisa, equivoca e até demagógica. Para Hayek, a economia não deveria se ocupar com temas "abstratos" como justiça social. 
como os Chicago boys. O que é mais lamentável nesse acontecimento histórico vergonhoso, é que a implantação forçada do programa neoliberal na América Latina e no Sul mundial, através de sua associação aos braços militares armados locais, não se deteve apenas na ditadura chilena, mas tem se tornado uma espécie de padrão. Essa experiência se repetiu no Peru de Fugimori, e tem se apropriado de outros governos autoritários como o de Rodrigo Duterte, nas Filipinas (que recebeu apoio de setores da elite econômica local para que implantasse um regime de terror contra a população, em nome do combate às drogas e a seus opositores, enquanto aprofunda um conjunto de reformas neoliberais no País). E a subida de Bolsonaro ao poder segue a mesma regra. Por trás de seu programa de militarização do Estado e de retirada de direitos civis e sociais, está seu ministro da economia Paulo Guedes, ele próprio um Chicago boy ortodoxo, formado em Chicago na escola de Friedman e Hayek, tendo trabalhado igualmente nas reformas econômicas do Chile durante a ditadura de Pinochet. A eleição de Bolsonaro, portanto, traz o Brasil de volta ao padrão latino-americano de aliança entre o autoritarismo militarizado e a desregulamentação forçada da economia, uma pauta de baixíssimo apelo eleitoral, mas que encontrou na linguagem bolsonarista o vocabulário popular perfeito para torná-la palatável a uma parcela da população. Que linguagem é essa?

A filosofia e a ideologia neoliberal reduzem tudo o que diz respeito ao espaço público a uma linguagem pautada exclusivamente sobre a noção de indivíduo - o chamado individualismo metodológico. Nesse processo de individualização de problemas sociais (que, na verdade, tem origem estrutural e sistêmica), as crises, fracassos e conquistas sociais - que são efeito direto de uma rede complexa e sobredeterminada de fatores econômicos e políticos de escala mundial -, recai sobre a responsabilidade dos atores individuais. Deste modo, o neoliberalismo tornou-se responsável pela colonização generalizada do espaço público pela linguagem da ação privada (Mises). Com isso, as questões públicas, que resistem a caber nesse modelo de explicação que reduz os fenômenos econômicos e sociais à ação privada, tornamse incompreensíveis e frequentemente são excluídas do debate público (as mazelas de um país tem que caber na explicação da ação individual de um governante que "gasta mais do que arrecada", ao contrário do que faria uma "dona de casa responsável"; ou a prática de corrupção de agentes políticos ou empresariais se torna 
explicação suficiente para a recessão econômica e para o desemprego de todo um país). Ora, quando a complexidade da situação é descartada, nos valemos daquilo que "está mais à mão" como causa das incertezas. A política torna-se um espaço personalista, composto por salvadores da pátria, mitos e líderes demagógicos. O círculo vicioso da "solução biográfica para problemas sistêmicos" se fecha quando se forja um inimigo com traços biográficos (movido por desejos ocultos individuais de poder e dominação, seja o PTista, o imigrante, ou até mesmo, no caso do Brasil, o demônio), a fim de explicar problemas estruturais. O espaço público se empobrece como campo de associações políticas e de solidariedade social, de modo que o único núcleo social admitido pela linguagem ideológica neoliberal é aquele núcleo, o mais rudimentar possível: o núcleo familiar. O "familiarismo" se estabelece como a única forma social aceita pela face conservadora da ortodoxia neoliberal atual. Mesmo que o apoio que o poder público oferecia às famílias esteja se degradando - com a precarização de políticas habitacionais, de renda e de educação pública -, o conservadorismo neoliberal de Bolsonaro tem rezado a cartilha da redução do campo social ao vocabulário da família, a ponto de voltar quase todas as suas políticas públicas, por exemplo, ao encerramento da educação pública ao núcleo familiar (com a permissão de que os pais eduquem seu filhos em casa, ao mesmo tempo em que corta verbas da educação pública), ao encerramento das políticas de segurança ao perímetro das propriedades familiares (com a ampliação da posse de armas para defesa da propriedade residencial e familiar), e com a revisão de temas educacionais que possam ferir a crença dos pais dos alunos (com o projeto chamado de "escola sem partido"). Nesse sentido, o neoliberalismo conservador produz uma desintegração do campo social, convertendo a sociedade em um conjunto de indivíduos isolados e atomizados, encerrados em pequenos núcleos sociais representados pelas famílias:

Como o neoliberalismo declara guerra [...] a própria ideia do que é público, ele dramaticamente dilui a vida pública sem matar a política [...] [o resultado é uma] política em meio a destruição da vida pública e especialmente da vida pública esclarecida, combinada à mercadologização da esfera pública, em partes o que faz da política contemporânea pouco atraente e tóxica - cheia de vociferações e imposturas, esvaziadas de seriedade intelectual, favorecendo um eleitorado deseducado e manipulável [...] (BROWN, 2015, p. 39). 
De um ponto de vista social e econômico, a liberalização e "desestatização" da economia tem produzido efeitos de desestabilização social irreversíveis. Desde os anos de 1990, com a implantação dessas políticas de agenda neoliberal, tem se intensificado os índices da desigualdade social no mundo. Segundo o relatório da OXFAM, a concentração de riqueza nos altos extratos sociais chegou a uma marca histórica assustadora: o 1\% mais rico da população mundial concentra $82 \%$ de toda a riqueza produzida no mundo, enquanto a parcela mais pobre da população não possui nenhuma riqueza material9. Além disso, as classes médias têm trabalhado com mais intensidade enquanto recebe pagamentos cada vez menores proporcionalmente. Essa da parcela da população é a que tem sofrido os maiores impactos, na medida em que tem sentido diretamente os efeitos de uma diminuição da segurança, de uma menor mobilidade social e da perda direta de direitos como aposentadoria estável e previsibilidade nas carreiras profissionais a longo prazo. O neoliberalismo tem forçado igualmente uma adulteração na linguagem ao se referir às políticas públicas de Estado. As funções estatais passam a ser medidas em linguagem econômica e a limitação dos serviços básicos que no modelo do Estado social deviam ser amplamente acessíveis, no modelo liberal são medidos em termos de "retorno", "gasto público" etc. A intimidade crescente entre capital financeiro e Estado jamais é problematizada - inclusive raras são as denuncias a respeito de como a financeirização da economia diminui a produtividade do Estado e das empresas -, mas "gastos" com infraestrutura, educação superior, pesquisa, saúde e acesso à terra como programas para famílias sem-terra, sem-teto e destinados a reservas indígenas -, tornam-se alvos de denúncias constantes de "gastos excessivos". O resultado da redução do corpo social à linguagem do indivíduo e da família, somado à linguagem economicista do "gasto" para se referir a direitos, produz o cenário ideal ao desmantelamento e a perseguição conservadora contra todas as instituições públicas que se utilizam da linguagem da associação e da solidariedade social: sindicatos, movimentos sociais e associações de classe são visto por princípio como uma ameaça social ou como parasitas aos que "realmente trabalham".

9 https://www.oxfam.org/en/pressroom/pressreleases/2018-01-22/richest-1-percent-bagged-82percent-wealth-created-last-year . Acesso em 21/05/2018. 

No Brasil

A linguagem dos vencedores e dos perdedores individuais em uma disputa de mérito se naturaliza e, como preconizava Hayek, deixa de ser tarefa do Estado garantir condições econômicas e sociais de justiça social para uma competição justa e um tratamento igualitário entre os cidadãos. O resultado é que a economia deixa de ser um mobilizador das potencias emancipatórias dos seres humanos e passa a apresentar uma face profundamente ambivalente: o interesse da classe capitalista é promover a auto expansão do capital ao seu mais alto grau possível, ou seja, promover o crescimento econômico de modo a garantir a estabilidade interna da organização capitalista. Mas essa "estabilidade interna" do sistema capitalista, através do crescimento econômico, apenas tem sido possível às custas da desestabilização externa de todos os outros subsistemas com os quais o capitalismo neoliberal se relaciona: a fim de manter o crescimento econômico capitalista estável, tem se produzido a desestabilização do sistema da natureza planetário, produzindo uma instabilidade climática jamais conhecida na história do planeta; tem se produzido igualmente uma desestabilização social radical, com a produção de um nível de desigualdade recorde na história humana e de um número crescente de desempregados e de pessoas sem-renda; tem se produzido igualmente uma desestabilização das fronteiras e das relações entre Estados e povos, produzindo um número sem precedentes de pessoas em busca de refúgio e de povos sem-pátria no cenário internacional; tem se produzido ao mesmo tempo uma desestabilização do sistema de acordos internacionais multilaterais e de organizações de blocos de cooperação no direito internacional, em nome do fechamento de fronteiras e do retorno das ideologias nacionalistas. Por tudo isso, a economia tem deixado de ser uma forma das sociedades se organizarem em busca de mais igualdade, estabilidade e mudança social, para se tornar uma fonte de desesperança coletiva, de imprevisibilidade política, de disputa e de ódio contra o outro. Parafraseando a famosa sentença de Mark Fisher (FISHER, 2014): a economia neoliberal tem se tornado responsável pelo lento cancelamento do nosso futuro.

Neste ponto reencontramos a apelativa guerra ao "marxismo cultural", que alimentou a eleição de Bolsonaro. Esse acirramento das disputas sociais e de guerra ao outro, somado ao combate/perda de certos privilégios que vinham se produzindo em certas democracias (como a brasileira) tem mobilizado um ódio social que tem se intensificado a partir da constatação da decadência dos padrões de vida, sobretudo 
entre as classes médias. Líderes autoritário de extrema-direita como Bolsonaro, tem instrumentalizado esse ódio ao mesmo tempo em que tem sido capaz de desviar a atenção das multidões para o fato de que grande parte das queixas típicas da extremadireita - a erosão dos padrões de vida e, por consequência, o enfraquecimento das estruturas familiares, o aumento da violência, a imigração em massa etc. - são, na verdade, efeitos diretos de mudanças do capitalismo monopolista atual e de suas novas formas de "flexibilização" neoliberal (que produzem instabilidade em relação aos postos de trabalho, nos salários, nas garantias de emprego etc.). Embora os números mostrem que este cenário mundial catastrófico tem se produzido a partir de uma desregulação e de uma financeirização da economia - representando uma colossal concentração de poder econômico nas mãos de uma pequena classe, às custas de uma degradação das condições de vida da maior parte dos indivíduos -, essas divisões econômicas e sociais raramente tem se traduzido em termos de divisões de classe na expressão pública comum e nos debates das redes sociais etc. Tais divisões se expressam mais comumente em termos de nacionalidade do que em termos de classe, propriamente. O nacionalismo tem assumido a forma ideológica de um chamado para as massas a 'fazerem parte da história", traduzindo problemas mundiais complexos em uma interpelação individual produzida em uma linguagem facilmente compreensível. Dito de outro modo: os nacionalismos têm oferecido um suposto protagonismo a cada indivíduo, diante de problemas estruturais grandes demais para serem compreendidos de maneira simples.

\section{As Carências do Capital Político De Bolsonaro, o lugar De Pai Da HoRda E SeUs IMPASSES}

É uma tarefa árdua conciliar um discurso ultradireitista de defesa patriótica da nação, com uma política "globalista" de abertura da economia, através de um Estado militar forte. Bolsonaro ainda não obteve sucesso nessa conciliação. Os primeiros meses do governo bolsonarista foram marcados pela tentativa constante de assentar as demandas (contraditórias entre si) de cada um dos grupos que o apoiaram eleitoralmente, buscando possibilitar um convívio, o menos tenso possível, entre os interesses antagônicos que emergiram de grupos políticos antagônicos, pacificados por sua promessa de um governo centralizador. Se a eleição de Bolsonaro foi 

No Brasil

garantida eleitoralmente pela confluência desses grupos, na passagem de seu capital eleitoral para o campo da articulação política, o governo tem se confrontado com as expectativas específicas de cada um desses blocos: embora todos tenham visto em Bolsonaro o principal impulsionador do antipetismo, alguns esperavam uma guinada neoliberal acelerada - e Bolsonaro tem enfrentado problemas com as políticas de Paulo Guedes em relação a Petrobrás e ao preço dos combustíveis e com sua orientação ao BNDES, por exemplo. Por outro lado, os generais, entre eles o próprio vice-presidente da república, enxergaram em Bolsonaro uma porta de entrada para a "re-institucionalização" dos militares ao poder, passando a limpo a imagem herdada a partir do Golpe de 64, e reconstruindo a relação entre as Forças Armadas e a população10. Assumindo seu lugar institucional no governo Bolsonaro, o exército teria a chance de desenhar um novo perfil: aquele de um poder ordeiro, capaz de "organizar a casa" dentro dos limites constitucionais. Seu retorno ao executivo através dos procedimentos institucionais democráticos, possibilitaria, ao mesmo tempo, organizar o próprio governo, dirigindo Bolsonaro pela contenção de seus excessos.

Mas a função totêmica que os generais almejavam, na garantia da institucionalidade do governo, tem se chocado frontalmente com a base mais "barulhenta" de apoio ao governo, para quem o presidente e seus filhos têm dedicado constante atenção. Esse grupo, que tem sido liderado simbolicamente pelo "olavismo" mas permanece disperso em certa gama de núcleos militantes, espera um governo com o perfil que sua tendência à extrema-direita e as declarações radicais de Bolsonaro prometeram: um perfil anti-institucional, que concentre o poder em poucas mãos e que seja capaz de capturar a democracia por dentro, corroendo as estruturas de equilíbrio de poder, isto é, controlando as universidades, a educação básica, 0 Supremo Tribunal Federal, a imprensa etc., e reduzindo a ampliação do horizonte de libertação democrático. Sua demanda é um Pai tirânico, capaz de assegurar a garantia da concentração de gozo e de privilégios de poder tradicionais.

Enquanto os militares do governo, para o bem de sua própria imagem, desejam forçar uma liderança institucionalizada ao governo; o núcleo duro populista da

10 Bolsonaro tem sentido a resistência dos generais em ingressar em sua onda de radicalização. Um exemplo disso foi a visibilidade nacional e internacional que Bolsonaro quis oferecer à celebração do Golpe militar de 1964. Enquanto os quadros militares do governo tentaram afastar sua imagem dos vínculos que as Forças Armadas possuem com a ditadura, a decisão monocrática de Bolsonaro buscou associar diretamente os militares ao Golpe, o que não encontrou eco entre seus ministros de Estado. 
militância bolsonarista espera uma ruptura com os militares - e, em certa dimensão, uma ruptura institucional - para que seu líder populista governe com plenos poderes. Em seus atos públicos, esse grupo demonstra apoio incondicional ao governo, se colocando contra o Congresso nacional (que passou a ser reduzido ao "centrão"), contra instituições como o STF e contra um possível golpe contra o governo. Essas atitudes mostram, não apenas que as forças militares no governo têm perdido a batalha na tentativa de "reorientar" a direção institucional do executivo, mas igualmente que o poder de mobilização total tem ganhado espaço sobre o poder de organização institucional do governo. Ocupando o lugar de uma espécie de "pai da horda", Bolsonaro é ao mesmo tempo tomado pelo temor de que os grupos que se "filiaram" ao bolsonarismo - seus filhos políticos - tentem destituí-lo, em um ato parricida (ato que se anunciaria depois de votada a Reforma da Previdência, que tem exigido uma contenção de ânimos políticos para ser aprovada). A violência social e o ódio entre grupos, não tendo sido capaz de se institucionalizar e se converter em capital político, permanece, ameaçados de retornar - como uma espécie de retorno no real de algo não simbolizado - em um ato violento de destituição do poder autoritário do pai-tirano. $O$ fato é que, em um círculo vicioso, a paranoia, fruto da impossibilidade de prever a direção a partir da qual o golpe virá, tem justificado posições ainda mais autoritárias e não-institucionais de um governo que possui apenas uma preocupação: conservar seu poder. E Bolsonaro tem razão em temer. 
O Ódio Como Afeto Político: Sobre A Composição Do Populismo De Extrema-Direita No Brasil

\section{REFERÊNCIAS}

ARENDT, H. Origens do totalitarismo: antissemitismo, imperialismo, totalitarismo. São Paulo: Cia. das Letras, 2012.

BENJAMIN, W. Magia e técnica, arte e política. Ensaios sobre literatura e história da cultura. Obras escolhidas, vol. I. São Paulo: Brasiliense, 1994.

BROWN, W. Undoing the demos: neoliberalism's stealth revolution. Nova York: Zone Books, 2015.

COOPER, M. Family values: between neoliberalism and the new social conservatism. Nova York: Zone books, 2017.

DERRIDA, J. Voyous. Deux essais sur la raison. Paris: Galilée, 2003.

FISHER, M. Ghosts of my life: writings on depression, hountology and lost futures. Alresford: Zero Books, 2014.

FREUD, S. Totem und Tabu / Das Unbehagen in der Kultur. Praga: Anaconda Verlag, 2010.

HAYEK, F. Individualism and economic order. Chicago: The University of Chicago Press, 1948.

Law, legislation and liberty. Londres: Routledge, 2012.

HOBBES, T. Leviatã, ou matéria, forma e poder de uma república eclesiástica e civil. São Paulo: Matins Fontes, 2003. 


\title{
The Hate As A Political Affect: On The Structure Of The Alt-Right Wing PopUlism In BRAZIL
}

\begin{abstract}
The hate appears in Freud's, Benjamin's and Arendt's work as a political instrument that makes possible to understand authoritarians and non-authoritarians tendencies in political organizations. In this article, I try to show how the institutional structure of democracy is incapable to avoid the internal destruction of democracy itself, nonetheless, it turns possible to offer a symbolical treatment to the hate. Starting form this reflection, I try to analyse some of the effects of the "bolsonarianism" in Brazil.
\end{abstract}

KEYwORDS: Hate; Psychoanalysis; Political philosophy; Bolsonaro; Democracy. 

No Brasil

\section{LA Haine Comme Affect Politique : SuR LA Composition Du POPULISME D'EXTREME-DroIt Au BRESIL}

\section{RÉSUMÉ}

La haine surgit dans l'œuvre de Freud, Benjamin et Arendt comme un instrument politique importante, capable de déterminer, d'une certaine façon, l'acheminement qu'on peut donner aux tendances autoritaires et non-autoritaires des organismes politiques. J'essaie de montrer dans cet article que les structures institutionnelles des démocraties ne sont pas capables d'éviter la destruction interne de la démocratie elle-même, mais par contre, elles rendent possible un traitement symbolique de la haine. À partir de cette réflexion, je souhaite analyser quelques effets du « bolsonarisme » au Brésil actuel.

MoTS-ÉcLÉs: Haine; Psychanalyse; Philosophie politique; Bolsonaro; Démocratie. 
( 2019 Psicanálise \& Barroco em revista

http://www.seer.unirio.br/index.php/psicanalise-barroco/index revista@psicanaliseebarroco.pro.br Programa de Pós-Graduação em Memória Social — UNIRIO Memória, Subjetividade e Criação www.memoriasocial.pro.br/proposta-area.php 